\title{
Recombinant Interferon Gamma
}

National Cancer Institute

\section{Source}

National Cancer Institute. Recombinant Interferon Gamma. NCI Thesaurus. Code C583.

A recombinant therapeutic agent which is chemically identical to or similar to the endogenous lymphokine interferon gamma (IFN-gamma) with antineoplastic, immunoregulatory, and antiviral activities. Therapeutic IFN-gamma binds to and activates the cell-surface IFN-gamma receptor, stimulating antibody-dependent cytotoxicity and enhances natural killer cell attachment to tumor cells. This agent also activates caspases, thereby inducing apoptosis in malignant cells. ( $\mathrm{NCl04)}$ 